\title{
Formation of ternary organic acids-Fe-P complexes on the growth of wheat (Triticum aestivum)
}

\author{
Djalma E. Schmitt ${ }^{1}$, Luciano C. Gatiboni ${ }^{2}$, Daniel J. D. Orsoletta ${ }^{3}$ \& Gustavo Brunetto ${ }^{4}$ \\ ${ }^{1}$ Universidade Federal de Santa Catarina/Centro de Ciências Rurais/Departamento de Agricultura, Biodiversidade e Florestas. Curitibanos, SC. E-mail: \\ djalma.schmitt@gmail.com (Corresponding author) - ORCID: 0000-0001-9665-9704 \\ ${ }^{2}$ Universidade do Estado de Santa Catarina/Centro de Ciências Agroveterinárias/Departamento de Solos e Recursos Naturais. Lages, SC. E-mail: \\ lgatiboni@gmail.com - ORCID: 0000-0001-8724-3600 \\ ${ }^{3}$ Universidade do Estado de Santa Catarina/Centro de Ciências Agroveterinárias/Programa de Pós-graduação em Ciência do Solo. Lages, SC. E-mail: \\ dani.orsoletta@gmail.com - ORCID: 0000-0003-0882-0073 \\ ${ }^{4}$ Universidade Federal de Santa Maria/Departamento de Solos. Santa Maria, RS. E-mail: brunetto.gustavo@gmail.com - ORCD: 0000-0002-3174-9992
}

Key words:

phosphate fertilization

available $\mathrm{P}$

subtropical soils

\begin{abstract}
A B S T R A C T
Phosphorus $(\mathrm{P})$ reacts with chemical and mineralogical constituents in the soil, mainly in tropical and subtropical soils. Therefore, strategies have been used to reduce the adsorption of $\mathrm{P}$ to the soil, among them, the formation of complexes that could decrease $\mathrm{P}$ adsorption to the soil. Two experiments were carried out to evaluate the formation of organic acidFe-P complexes in the laboratory and the efficiency of these complexes on the growth of wheat plants (T. aestivum) grown under greenhouse conditions. In experiment 1 , seven low-molecular-weight organic acids (OA) were selected and a protocol for the formation of complexes between organic acid and $\mathrm{Fe}^{3+}$ at $\mathrm{pH} 4.0$ was performed. After stirring, $\mathrm{P}$ was added to the organic acid-Fe complex to form the ternary complex. The remaining $\mathrm{P}$ was evaluated to determine the amount of $\mathrm{P}$ in the complex. In experiment 2 , the three OAs which had the largest amount of complexes were selected, together with a treatment with soluble $\mathrm{P}$ and a control. Wheat was grown in potted soil in a greenhouse for 34 days. The amount of ternary organic acid-Fe-P complexes formed varied from 5 to $42 \%$ of the added P. However, when these complexes were added to the soil, in treatments with greater amount of complex formed there was lower growth of wheat. Thus, the ternary complex with organic acid-Fe-P has little effect on the performance of wheat plants.
\end{abstract}

\section{Palavras-chave:} adubação fosfatada P disponível solos subtropicais

\section{Formação de complexos ternários de ácidos orgânicos-Fe-P no crescimento de trigo (Triticum aestivum)}

\section{RES U M O}

$\mathrm{O}$ fósforo $(\mathrm{P})$ reage com constituintes químicos e mineralógicos no solo, principalmente em solos tropicais e subtropicais. Por isso, estratégias têm sido utilizadas para diminuir a adsorção de $\mathrm{P}$ ao solo, dentre elas, a formação de complexos que poderiam diminuir a adsorção do $\mathrm{P}$ ao solo. Dois experimentos foram realizados com o objetivo de avaliar a formação de complexos ácido orgânico-Fe-P em laboratório e a eficiência desses complexos sobre o crescimento de plantas de trigo (T. aestivum), cultivadas em casa de vegetação. No experimento 1 foram selecionados sete ácidos orgânicos $(\mathrm{AO})$ de baixo peso molecular e realizado um protocolo de formação de complexos de ácido orgânico e $\mathrm{Fe}^{3+}$ a pH 4,0. Após a agitação foi adicionado $\mathrm{P}$ ao complexo ácido orgânico-Fe para a formação do complexo ternário. O P remanescente foi avaliado para determinar a quantidade de $\mathrm{P}$ no complexo. No experimento 2 , os três $\mathrm{AO}$ que apresentaram a maior quantidade de complexos foram selecionados, juntamente com um tratamento com $\mathrm{P}$ solúvel e um controle. $\mathrm{O}$ trigo foi cultivado em solo acondicionado em vasos em casa de vegetação por 34 dias. A quantidade de complexos ternários ácido orgânico-Fe-P formados variou 5 a $42 \%$ do $\mathrm{P}$ adicionado. Porém, quando esses complexos foram adicionados ao solo, nos tratamentos com maior quantidade de complexo formado houve menor crescimento do trigo. Assim, o complexo ternário com ácido orgânico-Fe-P é pouco efetivo no desempenho de plantas de trigo. 


\section{INTRODUCTION}

Phosphorus (P) has high interaction with chemical and mineralogical constituents in acid soils, such as subtropical soils (Yang et al., 2013; Khatiwada et al., 2014; Oliveira et al., 2014). Thus, it is common to apply $P$ in soils up to 5 times more than the amount extracted by crops (Simpson et al., 2011). Because of that, there is an interest in increasing the efficiency of phosphate fertilizers (Sousa Junior et al., 2017), since most of the fertilizer-derived $P$ reacts with the soil and a small part remains available to plants (Simpson et al., 2011; Santos et al., 2016). Products indicating higher efficiency of fertilization have appeared (Degryse et al., 2013; Urrutia et al., 2013), but they have small effect or even null effect on the increase of yield (Degryse et al., 2013; Chien et al., 2014).

The decomposition of organic residues and part of soil organic matter can provide low-molecular-weight organic acids (Pinheiro et al., 2013), increasing the efficiency of P for plants, especially by inhibiting $\mathrm{P}$ adsorption to the reactive sites of the soil (Yang et al., 2013). Several studies have demonstrated the formation of metal-organic materials complexes, which eventually reduces the activity of the metal in the solution (Guppy et al., 2005). Other studies have shown the formation of ternary complexes (Simanova et al., 2011), including those of phosphate-metal-humic acid, with a positive effect on the inhibition of P adsorption to the soil (Guardado et al., 2005, 2007, 2008; Urrutia et al., 2013).

Nevertheless, the formation of ternary complexes with the utilization of low-molecular-weight organic acids has not been tested yet. The hypotheses of this study are: (a) there is a formation of ternary organic acid-Fe-P complexes at the laboratory, (b) the amount of ternary complexes formed is similar, regardless of the organic acid used, and (c) the organic acid-Fe-P complex increases $\mathrm{P}$ absorption in comparison to the soluble source. The study aimed to evaluate the formation of organic acid-Fe-P complexes at the laboratory and their efficiency on the growth of wheat plants cultivated in a greenhouse.

\section{Material AND Methods}

\section{Experiment 1 - Formation of complexes at the laboratory}

The study was conducted at the Laboratory of Chemical and Soil Fertility of the Center of Agro-Veterinarian Sciences of the State University of Santa Catarina, in Lages (SC), Southern Brazil. The low-molecular-weight organic acids (Analytical reagent), acetic acid, malic acid, citric acid, tartaric acid, malonic acid, oxalic acid and succinic acid were selected to form ternary complexes. Acetic acid has 1 carboxylic group; malic, tartaric, malonic, oxalic and succinic acids have 2 carboxylic groups; and citric acid has 3 carboxylic groups.

The complexes were formed as follows: organic acids were added in 100-mL beakers, which received $70 \mathrm{~mL}$ of distilled water, followed by stirring with glass rod. The solution volume was gauged to $100 \mathrm{~mL}$ using distilled water. The concentrations of the acids were $0.1356,0.0678$ and $0.0452 \mathrm{M}$ for monocarboxylic acids (acetic acid), dicarboxylic acids (malic, tartaric, malonic, oxalic and succinic acids) and tricarboxylic acids (citric acid), respectively. A stock solution of Fe (III) nitrate was prepared with concentration of $0.1356 \mathrm{~mol} \mathrm{~L}^{-1} .50 \mathrm{~mL}$ of water, $10 \mathrm{~mL}$ of organic acid and $10 \mathrm{~mL}$ of the Fe nitrate solution at $\mathrm{pH} 4.0$ were added in a $100-\mathrm{mL}$ beaker. The volume of $100 \mathrm{~mL}$ was completed using distilled water. The solution was transferred to $200-\mathrm{mL}$ screw-cap flasks and shaken in Wagner shaker $\left(360^{\circ}\right.$ movement at $33 \mathrm{rpm}$ ) for $16 \mathrm{~h}$, in environment with temperature of $25^{\circ} \mathrm{C}$. Another 200-mL flask received $50 \mathrm{~mL}$ of distilled water and 10 $\mathrm{mL}$ of $0.01356 \mathrm{M}$ organic acid-Fe solution along with $10 \mathrm{~mL}$ of a $0.01356 \mathrm{M}$ solution of phosphoric acid at $\mathrm{pH}$ 3.5. The 0.01356 mol L-1 solution of phosphoric acid was added to the organic acid solution containing $\mathrm{Fe}$, under constant shaking, and gauged with $1.0 \mathrm{~mol} \mathrm{~L}^{-1} \mathrm{KOH}$ up to $\mathrm{pH}$ 4.0. The solution was gauged to $100 \mathrm{~mL}$ and transferred to $200-\mathrm{mL}$ screw-cap tubes and shaken for $16 \mathrm{~h}$. Five replicates were made for each complex. The final concentration of carboxylic group, Fe and P was $0.001356 \mathrm{M}$, which corresponds to a $\mathrm{P}$ concentration in the solution of $42 \mathrm{mg} \mathrm{L}^{-1}$, with a proportion of carboxylic group-Fe-P of 1:1:1.

\section{Experiment 2 - Evaluation of ternary complexes in greenhouse}

Acetic, malic and citric acids were selected from Experiment 1. Samples of a Nitossolo Vermelho (EMBRAPA, 2013) were collected in the $0-20 \mathrm{~cm}$ layer. The soil was air dried, grounded and sieved through a $2-\mathrm{mm}$ mesh. Part of the soil was subjected to chemical analysis, according to the methodology proposed by Tedesco et al. (1995). The soil had 504 and $36 \mathrm{~g} \mathrm{~kg}^{-1}$ of clay (pipette method) and organic matter, respectively; $\mathrm{pH}-\mathrm{H}_{2} \mathrm{O}$ of 4.2 (1:1 ratio); exchangeable $\mathrm{Al}^{3+}, \mathrm{Ca}^{2+}$ and $\mathrm{Mg}^{2+}(1 \mathrm{M} \mathrm{KCl}$ extractor) of $2.1 ; 2.0$ and 2.8 , respectively; available $\mathrm{P}$ and $\mathrm{K}$ (Mehlich-1 extractor) of 1.1 and $196 \mathrm{mg} \mathrm{dm}^{-3}$, respectively, and $\mathrm{CECpH}_{7.0}$ of $14.2 \mathrm{cmol}_{\mathrm{c}} \mathrm{dm}^{-3}$.

In the remaining soil $(80 \mathrm{~kg}), 0.54 \mathrm{~kg}$ of dolomitic limestone with recommendation for $\mathrm{pH} 5.5$ were added, homogenized and incubated for approximately 32 days. The soil was turned and weighed twice a week and, when needed, distilled water was added to maintain the moisture content at $80 \%$ field capacity.

Two $\mathrm{kg}$ of soil were added to pots with capacity for $2 \mathrm{~L}$. Six seeds of wheat (Triticum aestivum), cultivar Quartz, were sown in each pot. Five days after emergence, 4 plants were kept in each pot. At sowing, each pot received $20 \mathrm{~mL}$ of organic acid-Fe-P solution at dose equivalent to $125 \mathrm{~kg}$ of $\mathrm{P}_{2} \mathrm{O}_{5} \mathrm{ha}^{-1}$. The experimental design was completely randomized, with 4 replicates. Treatments were: 1) Ternary acetic acid-Fe-P complex; 2) Ternary malic acid-Fe-P complex; 3) Ternary citric acid-Fe-P complex; 4) Triple superphosphate; 5) Control, without $\mathrm{P}$ application.

The pots were arranged on benches in a greenhouse, where the temperature varied from 16 to $26^{\circ} \mathrm{C}$. Five days after emergence, each pot received $60 \mathrm{mg}$ of $\mathrm{N} \mathrm{kg}^{-1}$ of soil, using urea as source. At 34 days after emergence, shoots and roots were collected. A soil sample was also collected in each pot and homogenized. Then, roots were washed in abundant distilled water until complete removal of the soil. Shoots and roots were dried in an forced-air oven at $65^{\circ} \mathrm{C}$ until constant weight and ground in a Wiley-type mill. The tissue was prepared and subjected to sulfuric digestion, according to the methodology proposed by Tedesco et al. (1995). The soil was air dried, ground 
and sieved through a $2-\mathrm{mm}$ mesh. $\mathrm{P}$ was extracted using the Mehlich-1 method (Tedesco et al., 1995) and anion exchange resin (AER) (Raij \& Quaggio, 2001). The available P content in the soil (Mehlich-1 extractor) and $\mathrm{P}$ content in the tissue were extracted according to Tedesco et al. (1995). Soil P, tissue $\mathrm{P}$ and $\mathrm{P}$ from the solution of Experiment 1 were determined by colorimetry, following the methodology of Murphy \& Rilley (1962), by molecular absorption spectrophotometry.

In experiment 1 , the amount of complexed $\mathrm{P}$ was calculated by Eq. 1:

$$
\text { Pcomplexed }=\text { Ptotal }- \text { P read }
$$

where:

P complexed - Amount of $\mathrm{P}$ complexed, $\mathrm{mg} \mathrm{L}^{-1}$;

Ptotal - Amount of $\mathrm{P}$ added, $\mathrm{mg} \mathrm{L}^{-1}$; and,

Pread - Amount of $\mathrm{P}$ determined in solution, $\mathrm{mg} \mathrm{L}^{-1}$.

The results of the experiments were subjected to analysis of variance (ANOVA) and, when the effects were significant, means were compared by Tukey test $(\alpha=5 \%)$, using the software program Sisvar 5.6 (Ferreira, 2014).

\section{Results AND Discussion}

The highest values of complexes formed were observed in acetic acid, followed by malic, citric and tartaric acids (Figures $1 \mathrm{~A}$ and $\mathrm{B}$ ). The amounts of complexes formed in relation to the added amount of $\mathrm{P}$ varied from 4 to $42 \%$.

Although the same amounts of carboxylic groups were added for all complexes, and these at the same $\mathrm{pH}$ value, there were differences in the amounts of complexes formed. This can be due to the different $\mathrm{pKa}$ values of the acids, favoring the deprotonation of some acids, since they remained at the same $\mathrm{pH}$ values (Bolan et al., 1994). Because of that, the formation of complexes did not exhibit a linear trend through monocarboxylic and tricarboxylic organic acids but is associated with other factors, such as the capacity of oxidation by microorganisms (Oburger et al., 2011; Lai et al., 2017), besides the relative position of the $\mathrm{OH} / \mathrm{COOH}$ groups in their main chain (Hue et al., 1985).

Highest values of shoot and root dry matter production were observed in the treatments with application of triple superphosphate (soluble $\mathrm{P}$ ) and ternary citric acid-Fe-P complex (Figures 2A and B).

It is important that the treatment with citric acid-Fe-P had the lowest values of complexed $\mathrm{P}$ and, consequently, highest values of free $\mathrm{P}$ (Figure 1). On the other hand, the values of shoot and root dry matter production relative to the application of ternary acetic acid-Fe-P complex, which had larger amounts of complexes formed at the laboratory in Experiment 1, were similar to those observed in the control.

The values of $\mathrm{P}$ accumulated in the shoots were higher in treatments with application of soluble $\mathrm{P}$, citric acid-Fe-P complex and malic acid-Fe-P complex, and the control was similar to the acetic acid-Fe-P complex (Figure 2C). The P content accumulated by the roots had the same trend as the dry matter production, and the highest values were observed in soluble $\mathrm{P}$ and citric acid-Fe- $\mathrm{P}$ complex (Figure 2D). The application of acetic acid-Fe-P complex

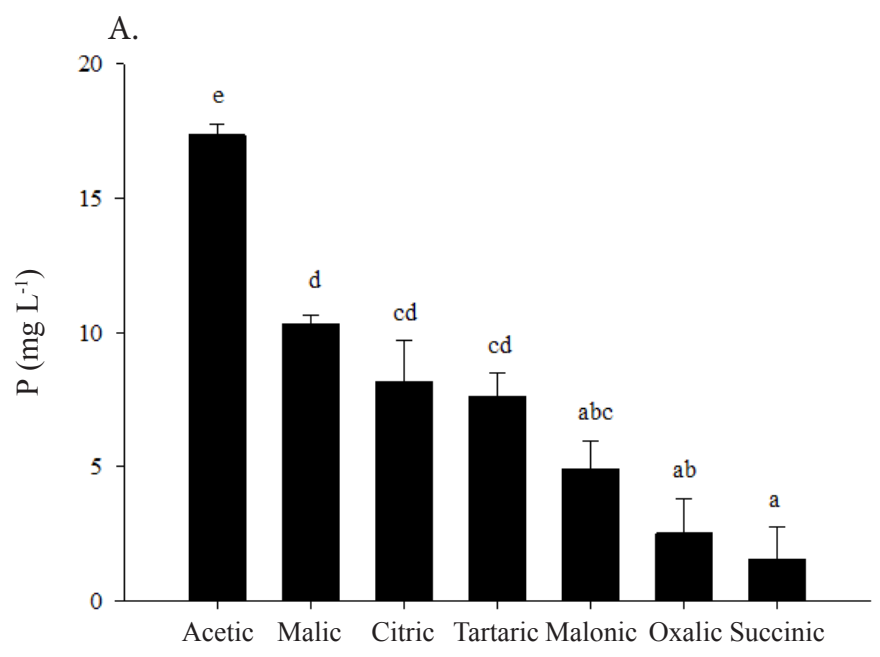

B.

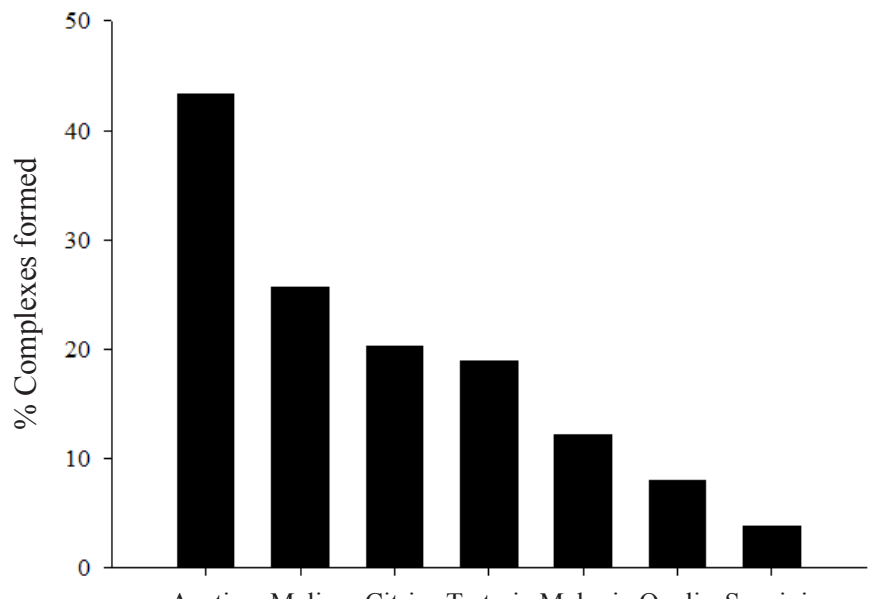

Acetic Malic Citric Tartaric Malonic Oxalic Succinic Legend: Acetic - Acetic acid; Malic - Malic acid; Citric - Citric acid; Tartaric - Tartaric acid; Oxalic - Oxalic acid; Succinic - Succinic acid; Means followed by the same letter do not differ significantly by Tukey test at 0.05 probability level. Bars represent the standard error of the measurements

Figure 1. Amount of $\mathrm{P}$ present in complexes (A) and percentage of complexes formed (B), after addition of different organic acids, Fe and $\mathrm{PO}_{4}^{-3}$ (1:1:1 molar ratio)

did not affect the amount of $\mathrm{P}$ accumulated in both shoots and roots compared with the control.

Higher dry matter production and accumulated $\mathrm{P}$ in soils under application of the citric acid-Fe-P complex shows that this complex may have had an effect on the reduction of $\mathrm{P}$ adsorption (Guppy et al., 2005) or on the complexation of soil $\mathrm{Al}^{3+}$ (Hue et al., 1985). It also demonstrates that the ternary complex has little effect on the inhibition of $\mathrm{P}$ adsorption to the reactive particles of the soil. In addition, the low values of P in the form of complex (20\%) cause this treatment to behave as free $\mathrm{P}$, in the soluble form. Although citrate has effect on the solubilization of inorganic P (Oburger et al., 2011), its application in the soil does not represent increase in wheat dry matter yield (Degryse et al., 2013). Thus, the formation of ternary complexes with organic acid-Fe-P is not significant in the increase in soil P availability.

Treatments with $\mathrm{P}$ application in the soil, regardless of the form, had the highest values of available $\mathrm{P}$ extracted by Mehlich-1 (Figure 3A). On the other hand, the values of $\mathrm{P}$ extracted by the AER were higher in the treatment with soluble $\mathrm{P}$ and in the treatment with application of malic acid-Fe-P organic complexes. However, all treatments with application 
A.

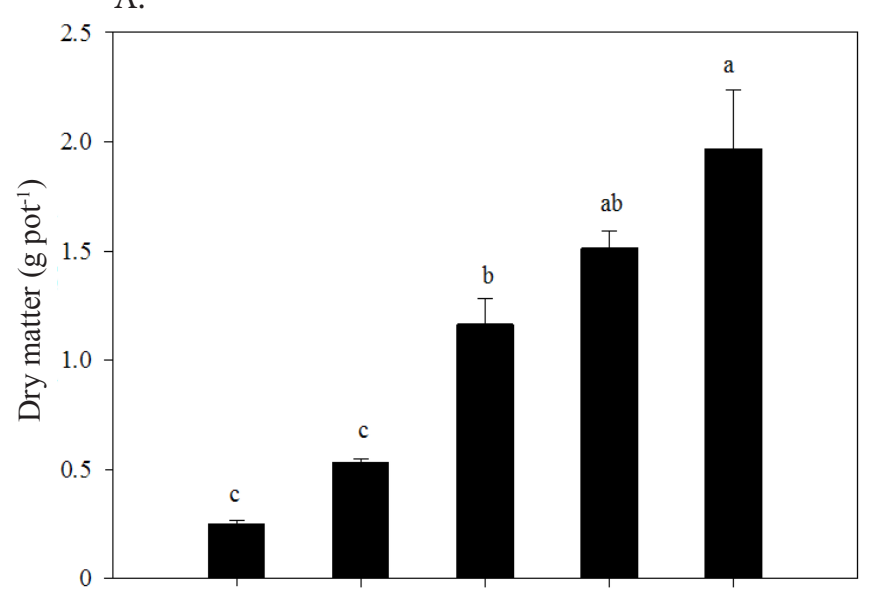

C.

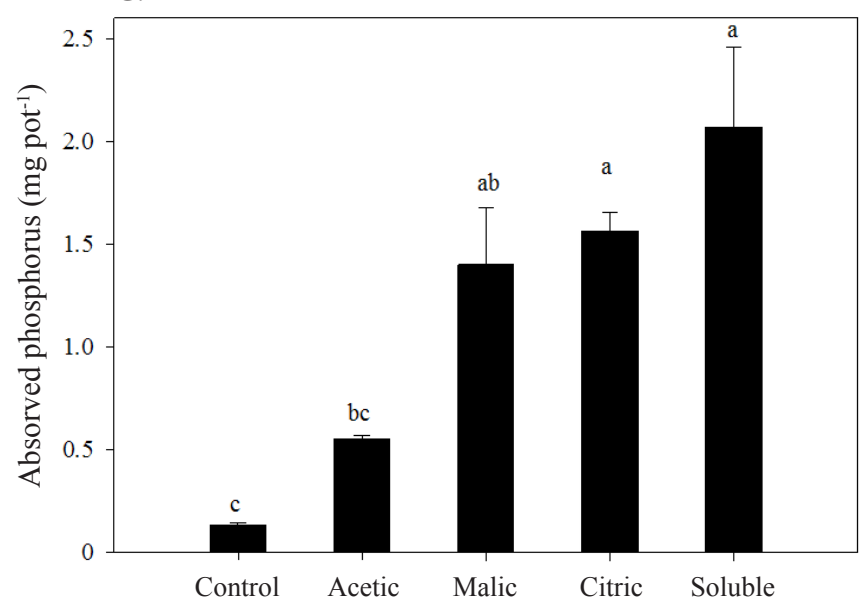

B.

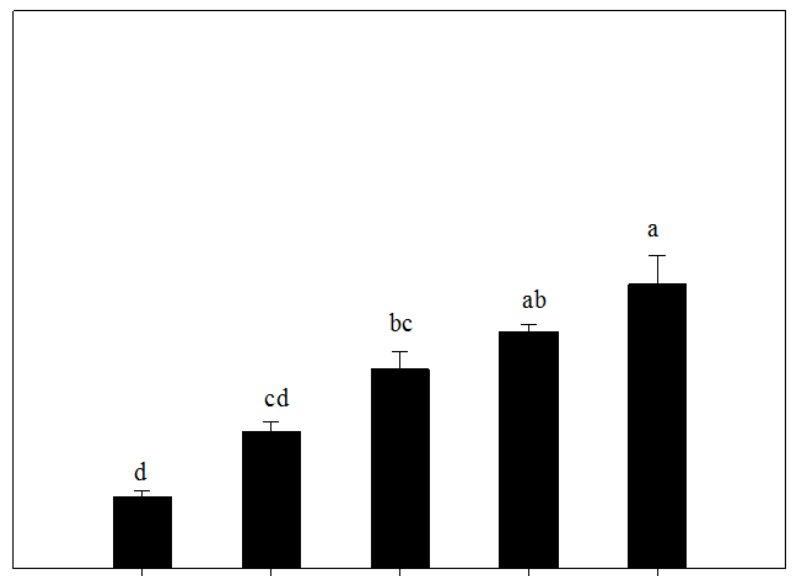

D.

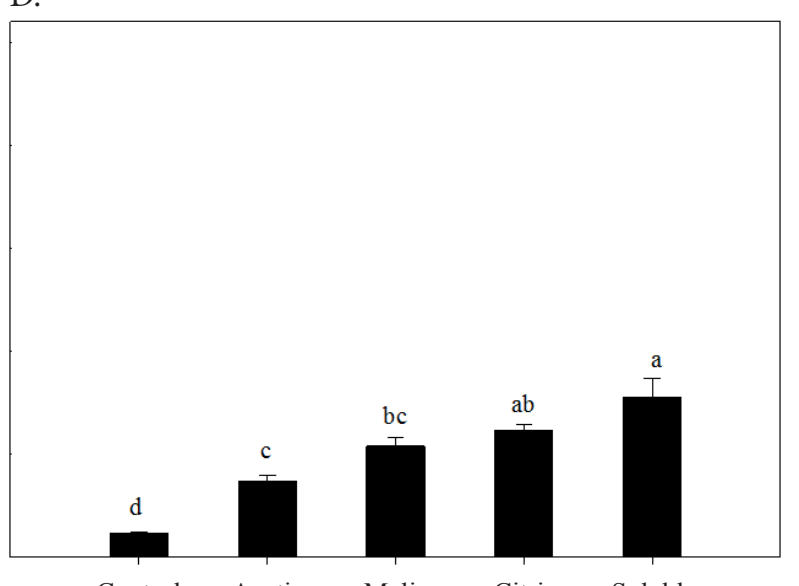

Legend: Control: Treatment without addition of organic acid; Acetic - Ternary complex with acetic acid; Malic - Ternary complex with malic acid; Citric - Ternary complex with citric acid; Soluble: Application of soluble fertilizer; Means followed by the same letter do not differ significantly by Tukey test at 0.05 probability level. Bars represent the standard error of the measurements

Figure 2. Shoot dry matter (A) and root dry matter (B), P accumulated in the shoots (C) and in the roots (D), as a function of the application of ternary complexes of organic acid-Fe-P, soluble P and a control, in a Red Nitosol cultivated with wheat in a greenhouse

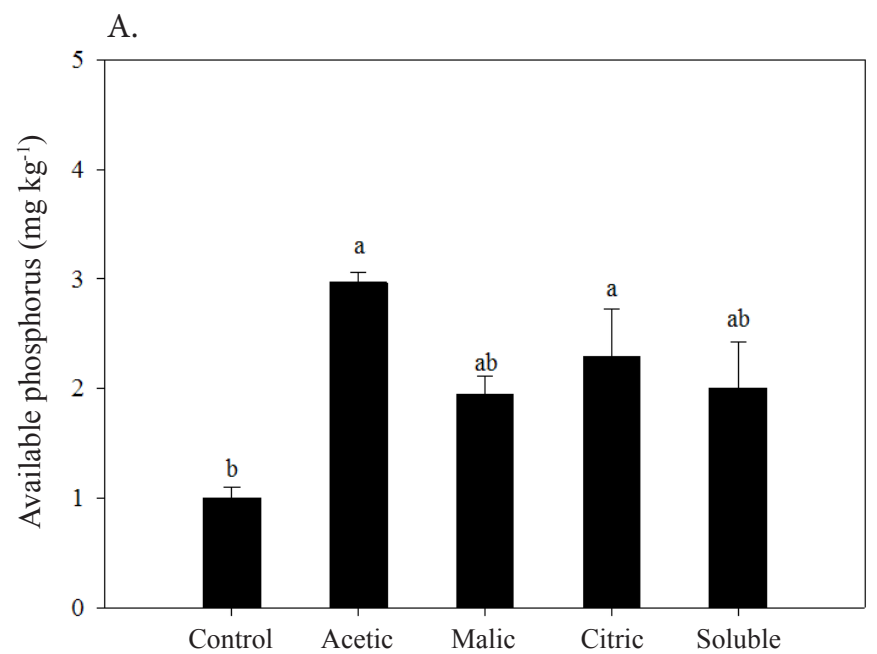

B.

Legend: Control: Treatment without addition of organic acid; Acetic - Ternary complex with acetic acid; Malic - Ternary complex with malic acid; Citric - Ternary complex with citric acid; Soluble: Application of soluble fertilizer; Means followed by the same letter do not differ significantly by Tukey test at 0.05 probability level. Bars represent the standard error of the measurements

Figure 3. Contents of available P extracted by Mehlich-1 (A) and anion exchange resin (AER) (B) in a Red Nitosol after application of complexes and cultivated with wheat in greenhouse

of $\mathrm{P}$ in the form of complexes were similar to each other and to the control (Figure 3B).

The amounts of $\mathrm{P}$ made available by the two extractors were different, which can be due to the mode of extraction of the different extractors, since the AER removes $P$ through an exchange without the modification of the soil (Silva \& Raij, 1999) and the Mehlich-1 is an acid extractor, being formed by strong acids at low concentration, which may have changed the complexes of the soil. 


\section{Conclusions}

1. The formation of ternary low-molecular-weight organic acid-Fe-P complexes was effective when conducted at the laboratory.

2. The application of these ternary complexes in the soil did not increase phosphate fertilization efficiency in the wheat crop.

\section{Literature Cited}

Bolan, N. S.; Naidu, R.; Mahimairaja, S.; Baskaran, S. Influence of low-molecular-weight organic acids on the solubilization of phosphates. Biology and Soil Fertilers, v.18, p.311-319, 1994. https://doi.org/10.1007/BF00570634

Chien, S. H.; Edmeades, D.; McBride, R.; Sahrawat, K. L. Review of maleic-itaconic acid copolymer purported as urease inhibitor and phosphorus enhancer in soils. Agronomy Journal, v.106, p.423430, 2014. https://doi.org/10.2134/agronj2013.0214

Degryse, F.; Ajiboye, B.; Armstrong, R. D.; McLaughlin, M. J. Sequestration of phosphorus-binding cations by complexing compounds is not a viable mechanism to increase phosphorus efficiency. Soil Science Society America Journal, v.77, p.2050-2059, 2013. https://doi.org/10.2136/sssaj2013.05.0165

EMBRAPA - Empresa Brasileira de Pesquisa Agropecuária. Sistema brasileiro de classificação de solos. 3.ed. Brasília: Embrapa Informação Tecnológica, 2013. 353p.

Ferreira, D. F. Sisvar: A guide for its bootstrap procedures in multiple comparisons. Ciência e Agrotecnologia, v.38, p.109-112, 2014. https://doi.org/10.1590/S1413-70542014000200001

Guardado, I.; Urrutia, O.; García-Mina, J. M. Methodological approach the study of the formation and physicochemical properties of phosphate-metal-humic complexes in solution. Journal of Agricultural and Food Chemistry, v.53, p.8673-8678, 2005. https://doi.org/10.1021/jf052031p

Guardado, I.; Urrutia, O.; García-Mina, J. M. Size distribution, complexing capacity, and stability of phosphate-metal-humic complexes. Journal of Agricultural and Food Chemistry, v.55, p.408-413, 2007. https://doi.org/10.1021/jf062894y

Guardado, I.; Urrutia, O.; García-Mina, J. M. Some structural and electronic features of the interaction of phosphate with metalhumic complexes. Journal of Agricultural and Food Chemistry, v.56, p.1035-1042, 2008. https://doi.org/10.1021/jf072641k

Guppy, C. N.; Menzies, N. W.; Moody, P. W.; Blamey, F. P. C. Competitive sorption reactions between phosphorus and organic matter in soil: A review. Australian Journal of Soil Research, v.43, p.189-202, 2005. https://doi.org/10.1071/SR04049

Hue, N. V.; Craddock, G. R.; Adams, F. Effect of organic acids on aluminum toxicity in subsoils. Soil Science Society America Journal, v.50, p.2834, 1985. https://doi.org/10.2136/sssaj1986.03615995005000010006x

Khatiwada, R.; Hettiarachchi, G. M.; Mengel, D. B.; Fei, M. Placement and source effects of phosphate fertilizers on phosphorus availability and reaction products in two reduced till soils: A greenhouse study. Soil Science, v.179, p.141-152, 2014. https:// doi.org/10.1097/SS.0000000000000055

Lai, R.; Arca, P.; Lagomarsino, A.; Cappai, C.; Seddaiu, G.; Demurtas, C. E.; Roggero, P. P. Manure fertilization increases soil respiration and creates a negative carbon budget in a Mediterranean maize (Zea mays L.) based cropping system. Catena, v.151, p.202-212, 2017. https://doi.org/10.1016/j.catena.2016.12.013
Murphy, J.; Riley, J. P. A modify single solution method for the determrnation of phosphate in natural waters. Analytica Chimica Acta, v.27, p.31-36, 1962. https://doi.org/10.1016/S00032670(00)88444-5

Oburger, E.; Jones, D. L.; Wenzel, W. W. Phosphorus saturation and $\mathrm{pH}$ differentially regulate the efficiency of organic acid anionmediated P solubilization mechanisms in soil. Plant Soil, v.341, p.363-382, 2011. https://doi.org/10.1007/s11104-010-0650-5

Oliveira, C. M. B.; Gatiboni, L. C.; Miquelluti, J. D.; Smyth, T. J.; Almeida, J. A. Capacidade máxima de adsorção de fósforo e constante de energia de ligação em Latossolo Bruno em razão de diferentes ajustes do modelo de Langmuir. Revista Brasileira de Ciência do Solo, v.38, p.1805-1815, 2014. https://doi.org/10.1590/ S0100-06832014000600015

Pinheiro, G. L.; Silva, C. A.; Lima, J. M.; Costa, A. L. Ácidos orgânicos de baixa massa molar em solos e materiais orgânicos. Química Nova, v.36, p.413-418, 2013. https://doi.org/10.1590/S010040422013000300011

Raij, B. van; Quaggio, J. A. Determinação de fósforo, cálcio, magnésio e potássio extraídos com resina trocadora de íons. In: Raij, B. van; Andrade, J. C.; Cantarella, H.; Quaggio, J. A. Análise química para avaliação da fertilidade de solos Tropicais. Campinas: Instituto Agronômico de Campinas, 2001. Cap.11, p.189-199.

Santos, H. S.; Oliveira, F. H. T.; Souza, A. P.; Salcedo, I. H.; Silva, V. D. M. Phosphorus availability as a function of its time of contact with different soils. Revista Brasileira de Engenharia Agrícola e Ambiental, v.20, p.996-1001, 2016. https://doi.org/10.1590/18071929/agriambi.v20n11p996-1001

Silva, F. C.; Raij, B. van. Disponibilidade de fósforo em solos avaliada por diferentes extratores. Pesquisa Agropecuária Brasileira, v.34, p.267288, 1999. https://doi.org/10.1590/S0100-204X1999000200016

Simanova, A. A.; Loring, J. S.; Persson, P. Formation of ternary metaloxalate surface complexes on *-FeOOH particles. Journal Physical Chemistry, v.115, p.21191-21198, 2011. https://doi.org/10.1021/ jp2058707

Simpson, R. J.; Oberson, A.; Culvenor, R. A.; Ryan, M. H.; VeneKlaas, E. J.; Lambers, H.; Lynch, J. P.; Ryan, P. R.; Delhaize, E.; Smith, A.; Smith, S. E.; Harvey, P. R.; Richardson, A. E. Strategies and agronomic interventions to improve the phosphorus-use efficiency of farming systems. Plant Soil, v.349, p.89-120, 2011. https://doi.org/10.1007/s11104-011-0880-1

Sousa Junior, P. R.; Brunharo, C. A. G.; Furlani, C. E. A.; Prado, R. M.; Maldonado Júnior, W.; Zerbato, C. Phosphorus fertilization in sugarcane cultivation under different soil managements. Revista Brasileira de Engenharia Agrícola e Ambiental, v.21, p.665-669, 2017. https://doi.org/10.1590/1807-1929/agriambi.v21n10p665-669

Tedesco, M. J.; Gianello, C.; Bissani, C.; Bohnen, H.; Volkweiss, S. J. Análise de solo, plantas e outros materiais. Porto Alegre: UFRS, 1995.174p.

Urrutia, O.; Guardado, I.; Erro, J.; Mandado, M.; García-Mina, J. M. Theoretical chemical characterization of phosphate-metalhumic complexes and relationhips with their effects on both phosphorus soil fixation and phosphorus availability for plants. Journal of the Science of Food and Agriculture, v.39, p.293-303, 2013. https://doi.org/10.1002/jsfa.5756

Yang, K.; Guan, L.; Zhu, J.; Yan, L. Effects of exogenous humic acids on forms of organic phosphorus in three contrasting types of soil. Communication Soil Science Plant Analysis, v.44 p.2095-2106, 2013. https://doi.org/10.1080/00103624.2013.799679 